\title{
ПЕНСІЙНЕ ЗАБЕЗПЕЧЕННЯ ДУХОВЕНСТВА ТА ЧЛЕНІВ ЇХ СІМЕЙ ВОЛИНСЬКОЇ ЄПАРХІЇ У ХІХ - ПОЧАТКУ ХХ СТ.
}

Анотація: Статтю присвячено вивченню основних етапів становлення пенсійного забезпечення духовенства, їх вдів і сиріт у Волинській єпархії протягом XIX - початку XX cm.

Встановлено, що в иілому матеріальне становище більшості позаштатного духовенства та членів їх сімей було вкрай скрутним. Держава почала приділяти иій проблемі увагу лише у другій половині ХІХ ст. Однак під вимоги для отримання пенсійних виплат підпадала досить незначна кількість церковнослужителів. Більшості з них і в похилому віці доводилося самотужки шукати шляхи для виживання. Вирішити цю проблему вдалося лише наприкіниі XIX - на початку XX cm., коли почали практично діяти емеритальні каси та пенсійні відрахування з їх платні було затверджено на державному рівні.

Ключові слова: пенсія, виплати, духовенство, Волинь, єпархія

Однією з болючих проблем життя духовенства, що тривалий час залишалася без вирішення, було пенсійне забезпечення позаштатного духовенства, їх вдів і сиріт. Становище цієї категорії церковнослужителів було набагато важчим, ніж бідноти інших станів. Зазначене питання є фрагментарно висвітлене у вітчизняній історіографії. В радянські часи дослідження у даному напрямку були під забороною, оскільки служителів культу вважали ворожим елементом. За часів незалежної України почалося активне вивчення різних аспектів життя та діяльності духовенства, однак саме питанню пенсійного забезпеченню не приділено належної уваги, хоча воно було досить важливим в їхньому житті. Єдина виявлена робота, яка присвячена пенсійному забезпеченню духовенства Чернігівської єпархії, на основі аналізу місцевих Єпархіальних відомостей, належить М. Блакитномуํㅡㄹ Однак кожна єпархія мала свої особливості. Тому метою даної статті є цілісне, комплексне та грунтовне дослідження особливостей пенсійного забезпечення духовенства однієї з єпархій Правобережної України - Волинської.

Перші спроби вирішення питання пенсійного забезпечення духовенства на Волині робилися ще у 20-х рр. XIX ст. На той час такими виплатами користувалося лише військове духовенство, священнослужителі так званих «ружних» церков, кафедральних соборів і міських парафій. Для решти духовенства єдиним засобом позаслужбового утримання було прийняття сиріт на казенний кошт до навчальних закладів, призначення на парафії замість

\footnotetext{
* Кондратюк Юлія Сергіївна - кандидат історичних наук, доцент кафедри гуманітарних і соціальних наук Державного університету «Житомирська політехніка» (Житомир, Україна); ORCID: https://orcid.org/0000-0002-5570-5505; e-mail: yulenka25@ukr.net

${ }^{1}$ Блакитний М.M. Пенсійне забезпечення церковнослужбовців Чернігівської єпархії у 80-х pp. XIX ст. (за матеріалами часопису «Черниговские епархиальные известия») // Сіверщина в історії України. 2013. Вип. 6. C. 363-367.
} 
престарілих, хворих і померлих священиків їх родичів, які б змогли підтримувати осиротілі сімейства, призначення вдів і незаміжніх сиріт жіночої статі на посади проскурниць. Усі ці засоби були далеко не ефективними й рідко приносили користь тим, для кого призначались. Тому для пошуку інших джерел допомоги 12 серпня 1823 р. було видано указ «0 призрении бедных духовного звания», зумовлений проханням деяких єпархіальних архієреїв про дозвіл на збір благодійних пожертвувань для позаштатних священиків, їх вдів і сиріт. Указ не передбачав виділення на ці потреби державних коштів, а лише зобов'язував єпархіальну владу упорядкувати збір добровільних пожертвувань, шляхом облаштування при церквах особливих карнавок і заведення підписних книг. Для безпосереднього розпорядження зібраними коштами створювались єпархіальні опікунства під головуванням місцевих архієреїв. До їх складу входило від трьох до шести членів-попечителів і по декілька співробітників у кожному повіті з числа місцевого духовенства².

До початку 60-х років XIX ст. позаштатне духовенство взагалі не користувалося правом державних пенсій. Лише указом від 30 січня 1861 р. було призначено кошти 3 державного казначейства на видачу пенсій і допомогу священнослужителям єпархіального відомства в сумі 180290 руб. Згодом, указом від 9 травня 1866 р. суму збільшили до 286000 руб. та розробили тимчасові пенсійні правила.

Правом на повний пенсійний оклад у розмірі 70 руб. на рік користувалися особи, які прослужили у священицькому сані не менше 35 років. При цьому священнослужитель, звільнений з посади судом і не виправданий, позбавлявся права на пенсію. Священики, які до виходу поза штат прослужили не менше 25 років, могли отримати від уряду лише одноразову допомогу в розмірі 70 руб. Враховуючи, що такого стажу досягали лише окремі особи, більшість священиків взагалі не могли розраховувати на будь-яку допомогу зі сторони держави. Стосовно вдів, то вони мали право на пенсію за службу чоловіка лише в разі, якщо той помер на службі після отримання права на повний пенсійний оклад, або знаходився поза штатом з пенсією або правом на неї. Пенсія у розмірі 45 руб. призначалася і вдовам священиків, які мали малолітніх дітей, невиліковно хворих, або інвалідів. Якщо священик будь-коли притягався до суду, або перебував під слідством і був виправданий та подальшою службою отримав право на пенсію, його вдова могла розраховувати на неповний пенсійний оклад у розмірі 55 руб. За тих же умов, але із врахуванням вислуги (не менше 25 років) вдовам виплачувалася одноразова допомога 70 рублів. Діти ж священиків, якого б віку вони не були, з втратою обох батьків позбавлялися й права на їх пенсію, чи будь-яку допомогу⿰氵

31 січня 1867 р. розмір пенсійних виплат вищезазначеним категоріям духовенства був збільшений до 90 руб., вдовам до 55 руб., вдовам з малолітніми дітьми та дітьми інвалідами до 65 руб. ${ }^{4}$

Існував порядок публікації у місцевих «Єпархіальних відомостях» списків осіб, яким призначалися пенсії та допомоги. Адресати самі мали приїздити до консисторії й отримувати гроші. Однак така практика виявилася вкрай невдалою. По-перше, виписка

\footnotetext{
${ }^{2}$ Полное собрание законов Российской империи (далі - ПС3). Т. XXXVIII. Санкт-Петербург, №29583. С. 11691177.

${ }^{3}$ ПС3. T. XLI. № 43288 . С. 531-537.

${ }^{4}$ ПС 3 . T. XLI. № 43970 . С. 374.
} 
«Єпархіальних відомостей» була обов'язковою лише для діючих священнослужителів, подруге - приїхати 3 віддалених повітів до Житомира іноді коштувало вдові чи сироті дорожче, ніж сам розмір допомоги. Тому з 1893 р. видачу асигнованих грошових сум за призначенням було покладено на благочинних.

3 80-х років XIX ст. намітилась тенденція до все більшого зростання державних витрат на утримання духовенства, в тому числі й на пенсійне забезпечення. У 1902 р. було розроблено та затверджено новий статут про пенсії й одноразові допомоги. Їх розмір визначався відповідно до службового становища пенсіонера та строку вислуги. Так, позаштатний кафедральний протоієрей отримував 500 руб., сільські та міські священики 200, диякони та псаломщики - 100 руб. Священики, котрі мали більше 35 років вислуги отримували пенсію у повному розмірі свого річного заробітку, понад 30 років - у розмірі двох третин, від 20 до 30 років - третину заробітку. Вдовам померлих призначалися пенсії в розмірі половини пенсії їхніх чоловіків, окрім того третина додавалася на кожну малолітню дитину. Круглі сироти отримували четверту частину пенсії своїх батьків ${ }^{5}$. Наказом Синоду від 18 березня 1903 р. право на одержання одноразових допомог отримали духовні особи, які не мали достатньої вислуги. Їм виділялися кошти як 3 місцевого єпархіального опікунства, так і з загального пенсійного фонду.

Певну роль у забезпеченні духовенства відігравали церковнопарафіяльні опікунства, які створювалися на Волині, починаючи з 1823 р. Їх головним завданням була опіка над благоустроєм церкви, влаштування початкових сільських училищ, заходи благодійного характеру. Склад членів обирався загальними зборами парафіян. До числа обовязкових членів входили: місцевий священик, волосний старшина і сільський голова. Як громадські організації, то опікунства були підзвітні загальним зборам сільської громади. Кошти парафіяльних опікунств складалися 3 добровільних пожертв їх членів, прибутків від ситування меду у храмові свята, зборів і пожертв доброчинців, віншувань і колядок, продажу ікон, хрестиків тощо. Крім того, до 1862 р. Синод щорічно відпускав спеціальну суму в розмірі 4500 руб., з них 500 - на потреби самих опікунств і 4000 на утримання бідного духовенства. Однак з 1863 р. відпуск коштів було припинено. У той же час на єпархіальні опікунства було покладено низку нових обов'язків, пов'язаних із значною витратою і без того мізерних матеріальних коштів: утримання та лікування хворих священиків і церковнослужителів у міських лікарнях, видача допомоги духовним особам при пожежах, завідування опікунськими справами тощо.

Загалом, єпархіальні опікунства мали у своєму розпорядженні досить скромні кошти, що часто не могли задовольнити навіть нагальних потреб. Волинське єпархіальне опікунство було одним з найбідніших, у порівнянні з іншими аналогічними установами. Його основний капітал на 1873 рік становив у банківських білетах 22165 руб. Крім того, протягом всього року готівкою надійшло лише 3644 руб. Видаткова частина склала 3459 руб., $з$ них 3258 власне на забезпечення 648 родин духовенства. Для порівняння, у той же час, на рахунках Київського опікунства налічувався 61441 руб. ${ }^{6}$

Церковнопарафіяльні опікунства були громадськими організаціями і їх створення на місцях майже цілковито залежало від активності парафіян та ініціативи самих священиків.

\footnotetext{
${ }^{5}$ Волынские епархиальные ведомости (далі - ВЕВ). 1902. № 20, часть офиц. С. 463.

${ }^{6}$ BEB. 1874. № 16. ч. oф. С. 231.
} 
Процес їх масового створення припав на середину 1860-х років, відповідно до указу Синоду від 2 серпня 1864 р. ${ }^{7}$ У Волинській єпархії, станом на 1892 рік їх налічувалося $256^{8}$.

3 другої половини XIX ст. одним із способів поліпшення матеріального становища духовенства стали емеритальні каси, що створювалися за ініціативою духовенства на місцях. На Волині, ідею створення такого інституту вперше подав у 1868 р. благочинний 4го округу Новоград-Волинського повіту Іоанн Лібацький. У рапорті, поданому 20 грудня 1868 р. на розгляд Волинської духовної консисторії, він просив дозволу заснувати окружне товариство опіки над бідними особами духовного звання, під назвою «Товариство духовноемеритальної каси». Саме на цей час припав вихід урядової постанови про скасування практики наслідування парафій. В умовах, коли право на пенсійний оклад міг заслужити далеко не кожний священик, а решта членів причту взагалі були позбавлені цього, їх сімї̈, у разі передчасної смерті або хвороби годувальника, позбавлялися останніх засобів на існування.

Проєкт Іоанна Лібацького полягав у наступному. Членами товариства мали бути всі штатні священики та церковнослужителі округу, а також духовенство інших, у разі виявлення ними такого бажання. Завідування касою доручалося благочинному та кільком найбільш шанованим священикам. Метою каси було надання допомоги позаштатним священикам, церковнослужителям та їхнім сім'ям, як додаток до державних пенсій i допомог. Джерелами поповнення каси були обов'язкові відрахування від платні кожного члену парафії, карнавковий збір і добровільні пожертвування, штрафні та нагородні збори. Останні розподілялися відповідно до ступеня нагороди. Так, священики, які отримали архієрейське благословення, мали вносити до каси 50 коп., набедреник - 1 руб., скуфію 2 руб. Найбілыші внески сплачували протоієреї - 7 руб. та орденські кавалери - 12 руб.

3 метою запобігання зловживанням і безпідставних витрат, всі надходження готівкою, за винятком суми на поточні витрати, мали негайно пересилатися до банку для конвертації їх у відсоткові кредитні білети. Виплата емеритальної допомоги передбачалася через 5 років з часу заснування каси, тобто до накопичення відповідного капіталу. Правом на пожиттєву емеритальну допомогу могли скористатися священики та церковнослужителі, які сплачували внески не менше 15 років, а також їх вдови та сироти. Решта платників каси, строк виплат яких становив від 9 до 15 років, могли отримувати допомогу «на усмотрение» товариства. Виняток становили лише особи, які змушені були залишити службу в результаті важких і невиліковних хвороб. Ця категорія користувалася правом на пожиттєву допомогу нарівні з тими, хто прослужив 35 років, але у розмірі, залежному від кількості виплатних років. Права на емеритальну допомогу позбавлялися особи, які були виключені з духовного сану за кримінальні злочини.

Постановою Волинської духовної консисторії від 19 травня 1869 р. проєкт Іоанна Лібацького був сприйнятий цілком позитивно, але міг бути реалізований лише у разі створення подібних товариств і в інших округах єпархії. Остаточний його розгляд передавався на обговорення благочинницьких зборів духовенства'

\footnotetext{
${ }^{7}$ ПС3. Т. XXXIX. № 41144. С. 689.

${ }^{8}$ Девятсотлетие православия на Волыни: 992-1892 гг. Ч. ІІ: Статистические сведения о приходах Волынской епархии. Житомир, 1892. С. 2-589.

${ }^{9}$ BEB. 1869. № 167. ч. оф. С. 448-457.
} 
У 70-80-х роках XIX ст. питання про створення емеритури піднімалось окремими представниками волинського духовенства, як на сторінках преси, так і на офіційних загальноєпархіальних зборах. Проте воно тривалий час не знаходило свого остаточного вирішення. На причини цього проливає світло доповідна записка священика села Барбарівки Заславського повіту Христофора Захаріяшевича. Він пояснював, що затягування iз заснуванням емеритури відбувається через неодностайність думок єпархіального духовенства щодо їі форм. Так, за проєктом священика Павла Стефановича - це мала бути каса взаємодопомоги ${ }^{10}$, автор іншого проєкту - священик Іван Ганжулевич пропонував створення каси страхування життя ${ }^{11}$ тощо.

У низці єпархій установи на зразок емеритури почали створюватися за ініціативою духовенства ще з кінця 60-х років XIX ст. Проте на державному рівні відрахування пенсійних внесків 3 платні духовенства було запроваджене лише у 1888 р. постановою Синоду від 22 червня ${ }^{12}$. Зокрема, статут емеритальної каси Волинської єпархії було розроблено на єпархіальному з'їзді 1893 р. і затверджено Синодом у 1896 р. Членами каси в обов'язковому порядку були всі штатні та позаштатні священики та церковнослужителі. Вона знаходилася у безпосередньому віданні архієрея. у перші 10 років після відкриття емеритури внески передбачалися у таких розмірах: по 18 руб. від кожного священика та по 9 руб. від псаломщика та паламаря. Крім того, прибутки надходили від відсотків 3 капіталу та 2\% відрахувань 3 пенсій емеритів, добровільних пожертвувань, обов'язкових зборів на випадок передчасної смерті. За новим статутом каси від 1913 р. річні внески до емеритури було збільшено та розподілено на три категорії. Священицький внесок став 24 рублі, дияконський - 12, паломницький - 6. Статутом відмінялися усі додаткові збори. Священики, які в силу будь-яких причин позбавлялися сану, лишалися й пенсії, але їхні сім'ї отримували кошти на загальних підставах. Бездітні члени каси отримували гроші відповідно сумі сплачених внесків. Кошти з емеритальної каси видавалися вкладникам після зарахування за штат, або у разі смерті - вдовам і дітям. При відсутності останніх сума з відсотками переходила у власність каси.

Емеритальні пенсії одержували також і діти священиків і церковнослужителів, які народилися після виходу батьків поза штат. Сини вкладників отримували пенсії до 28 років, доньки - довічно, або до моменту заміжжя, чи прийняття на службу з окладом понад 150 руб. У решті випадків пенсії дітям призначалися лише калікам, невиліковно хворим і вкрай зубожілим.

Загалом, мінімальний розмір емеритальної пенсії священика на 1913 рік становив 60 руб., максимальний - 240, диякона - відповідно 30 і 120, псаломщика - 15 і 60².

Отже, проблема забезпечення позаштатного духовенства, їх вдів і сиріт завжди стояла досить гостро. До середини XIX ст. ці люди не отримували належної допомоги та мали самотужки шукати шляхи для виживання. Враховуючи численні прохання духовенства, в 60-х роках XIX ст. ситуація дещо покращилася і держава звернула на нього увагу. Однак на призначені з державного казначейства кошти могли претендувати лише

\footnotetext{
${ }^{10}$ BEB. 1881. № 31. ч. неоф. С. 1057-1066.

${ }^{11}$ ВЕВ. 1881. № 33. ч. неоф. С. 1109-1120.

${ }^{12}$ BEB. 1888. № 24. ч. оф. С. 407-408.

${ }^{13}$ BEB. 1913. № 48. ч. неоф. С. 861.
} 
окремі особи, котрі мали вислуги не менше 35 років. Тому становище усіх інших залишалося плачевним. У разі смерті зазначеної категорії священиків, належні їм виплати переходили вдовам і сиротам. Допомогу призначали і тим вдовам, які мали неповнолітніх дітей, з невиліковними хворобами, або інвалідів. У 80-х роках ХІХ ст. ситуація незначною мірою покращилася, оскільки термін вислуги для права отримувати пенсію було знижено до 20 років. Матеріальна стабільність для духовенства пенсійного віку та їхніх сімей настала лише наприкінці XIX - на початку XX ст., коли почали повноцінно діяти емеритальні каси і пенсійні відрахування з їх платні було затверджено на державному рівні.

Julia Kondratyuk

\section{Pension Provision of the Clergy and Members of their Families of the Volyn Diocese in the XIX - early XX centuries}

Abstract: The article is devoted to the study of the main stages of the formation of the pension provision of the clergy, their widows and orphans in the Volyn diocese during the XIX - early XX centuries.

It was found that in general the material majority of the freelance clergy and members of their families was extremely difficult. The state began to pay attention to this problem only in the second half of the nineteenth century. Given the numerous requests of the clergy in the 1860s, the situation improved somewhat. However, only individuals who had served for at least 35 years could apply for funds from the state treasury. Therefore, the situation of all others remained deplorable. Most of them had to look for ways to survive on their own in old age. In the event of the death of eligible priests, the payments due to them went to widows and orphans. Assistance was also provided to widows who had minor children with incurable diseases or the disabled.

As a result of the study it was found that in the 80s of the XIX century the situation has slightly improved as the length of service has been reduced to 20 years for the right to receive a pension.

Material stability for freelance clergy and their families came only in the late nineteenth and early twentieth centuries, when emeritus funds began to operate in practice and pension contributions from their salaries were approved at the state level.

Keywords: pension, payments, clergy, Volyn, eparchy 